\title{
Turbulence as a driver for vertical plankton distribution in the subsurface upper ocean
}

\author{
DIEGO MACÍAS ${ }^{1}$, ÁNGEL RODRÍGUEZ-SANTANA ${ }^{2}$, EDUARDO \\ RAMÍREZ-ROMERO ${ }^{3}$, MIGUEL BRUNO $^{4}$, JOSEP L. PELEGRÍ ${ }^{5}$, PABLO SANGRÀ $^{2}$, \\ BORJA AGUIAR-GONZÁLEZ ${ }^{2}$ and CARLOS M. GARCÍA ${ }^{3}$ \\ ${ }^{1}$ European Commission, Joint Research Center, Institute for Environment and Sustainability, Water Research Unit, \\ Via E. Fermi 2547, 21027-Ispra, Italy. E-mail: diego.macias-moy@jrc.ec.europa.eu \\ ${ }^{2}$ Departamento de Física, Universidad de Las Palmas de Gran Canaria, Campus Universitario de Tafira, \\ 35017 Las Palmas de Gran Canaria, Spain. \\ ${ }^{3}$ Departamento de Biología, University of Cadiz, 11510 Puerto Real, Cadiz, Spain. \\ ${ }^{4}$ Departamento de Física Aplicada, University of Cadiz, 11510 Puerto Real, Cadiz, Spain. \\ ${ }^{5}$ Institut de Ciències del Mar, CSIC, 08003 Barcelona, Spain.
}

\begin{abstract}
SUMMARY: Vertical distributions of turbulent energy dissipation rates and fluorescence were measured simultaneously with a high-resolution micro-profiler in four different oceanographic regions, from temperate to polar and from coastal to open waters settings. High fluorescence values, forming a deep chlorophyll maximum (DCM), were often located in weakly stratified portions of the upper water column, just below layers with maximum levels of turbulent energy dissipation rate. In the vicinity of the DCM, a significant negative relationship between fluorescence and turbulent energy dissipation rate was found. We discuss the mechanisms that may explain the observed patterns of planktonic biomass distribution within the ocean mixed layer, including a vertically variable diffusion coefficient and the alteration of the cells' sinking velocity by turbulent motion. These findings provide further insight into the processes controlling the vertical distribution of the pelagic community and position of the DCM.
\end{abstract}

Keywords: turbulence, deep chlorophyll maximum, vertical plankton distribution.

RESUMEN: LA TURBULENCIA COMO MECANISMO FORZANTE DE LA DISTRIBUCIÓN VERTICAL DEL PLANCTON EN EL OCÉANO SUBSUPERFICIAL. - Las distribuciones verticales de la tasa de disipación de la energía turbulenta y de la fluorescencia han sido medidas simultáneamente usando un microperfilador de alta resolución en cuatro regiones oceánicas distintas, desde zonas templadas a polares y desde regiones costeras al océano abierto. Valores altos de fluorescencia, conformando un máximo profundo de clorofila (MPC) fueron detectados habitualmente en regiones poco estratificadas de la columna de agua y justo por debajo de capas con valores máximos de la tasa de disipación de la energía turbulenta. En las cercanías del MPC se encontró una relación estadísticamente significativa y negativa entre los valores de fluorescencia y energía turbulenta. En este trabajo se discuten los posibles mecanismos que pueden explicar estas relaciones, incluyendo el efecto de la variación vertical del coeficiente de difusión y la posible alteración de la velocidad de sedimentación de las células de fitoplancton por el movimiento turbulento. Estos resultados proporcionan un mayor conocimiento sobre los procesos que controlan la distribución vertical de la comunidad pelágica y la posición de los MPC.

Palabras clave: turbulencia, máximo profundo de clorofila, distribución vertical del plancton.

\section{INTRODUCTION}

Turbulence is a ubiquitous feature of geophysical fluids that typically arises as a consequence of energy transfer from large to small scales (Kolmogorov 1941).
In marine ecosystems, small organisms with little or no motility, such as phytoplankton cells, are immersed in a turbulent environment that influences numerous biological processes, including photosynthesis (Belyaev 1992), nutrient uptake (Lazier and Mann 1989, Bowen 
et al. 1993), encounter and grazing rates (Rothschild and Osborn 1988) and even community composition (Margalef 1978, Falkowski and Oliver 2007). The distribution of plankton, in particular its patchiness, is also related to the turbulent nature of movements in the upper ocean (Platt 1972) in both the horizontal and vertical dimensions (Abraham 1998, Franks 2005, d'Ovidio et al. 2010).

One of the most common features of the vertical distribution of plankton is the presence of a deep chlorophyll maximum (DCM) (Cullen 1982). The existence of a DCM may be initially explained by the presence of two vertically opposing gradients of resources that control the vertical distribution of planktonic biomass: light availability from the surface and a high nutrient concentration in deep waters (Longhurst and Harrison 1989). The biomass of photosynthetic plankton organisms is accumulated in a narrow region where there is sufficient light for photosynthetic activity and sufficient inorganic nutrients to allow net positive growth.

There is evidence that in some circumstances photoacclimation (i.e. the change of the chlorophyll content per cell) could also explain the apparition of DCM (Falkowski et al. 1998, Fennel and Boss 2003). This holds true in the subtropical ocean where the DCM does not usually coincide with maxima of cell abundance, biomass or primary production (e.g., Zubkov et al. 2000, Pérez et al. 2006). Within the euphotic zone the chlorophyll-to-carbon (Chl:C) ratio generally increases with depth (Cullen and Lewis 1988), so a deep biomass maximum (DBM) may often be slightly displaced down with respect to the DCM. This is especially true in summer or in tropical waters, whereas during the early productive season in temperate waters these maxima tend to coincide.

While the reasons for the presence of DCM in the surface oceanic layer are well established, the mechanisms controlling the precise vertical position of those DCM within the water column are still under debate. Both biological and physical processes have been invoked to explain the DCM vertical location. The proposed biological processes include preferential production at the nutricline (as explained above), phytoplankton behavioural aspects (e.g. variations in cell buoyancy) and adaptive changes in the $\mathrm{Chl}: \mathrm{C}$ ratio (Cullen 1982, Falkoswki et al. 1998, Fennel and Boss 2003). Physical processes include changes in the sinking velocity across density gradients (Riley et al. 1949, Bienfang 1980) and horizontal intrusions and erosions associated with water movements (Mann and Lazier 1991). All these mechanisms are not exclusive and could jointly help to control the DCM position within the water column.

The role of turbulence in shaping the vertical distribution of planktonic biomass has puzzled oceanographers for a long time. The influence of turbulence both on the vertical distribution of plankton and on the characteristics of DCM in natural waters is not fully understood, partly because of a lack of appropriate measurements. The difficulty of directly measuring turbulence in natural waters (e.g. Kiørboe 1993) has resulted in the utilization of several proxies. One commonly used is vertical stratification, as it is assumed that turbulence should be weak (strong) in stratified (unstratified) portions of the water column (Jassby and Powell 1975). Therefore, the relationship between turbulence and vertical plankton distribution is often discussed in terms of the stratification characteristics of the water column (e.g. Abbott et al. 1984, Fasham et al. 1985, Seuront and Lagadeuc 1997). However, as clearly presented by Brainerd and Gregg (1995), the mixed layer (the weakly stratified portion of the water column) does not always correspond with the mixing layer, the region of the water column with high turbulence values.

The development of high frequency micro-profilers has made it possible to obtain more accurate measurements of the structure of turbulent motion (e.g. Lewis et al. 1984). In recent years, a commercially available turbulence microprobe (TurboMAP, Wolk et al. 2002) has led to an increasing number of field studies on turbulence and planktonic distributions (e.g. Yamazaki et al. 2006 and 2010, Doubell et al. 2009, Prairie et al. 2011). Most of these studies have focused on the sub-centimetre (microscale) structure of the turbulent field (Wolk et al. 2002, Yamazaki et al. 2006) and the associated biological signatures (Doubell et al. 2009); only two studies have examined the macroscopic ( $>1$ metre) patterns that emerge from microscale interactions (Yamazaki et al. 2010, Prairie et al. 2011). Moreover, all these previous studies focused on a single site or region.

The main aim of the present study is to use an extensive TurboMAP data set in order to examine the relationship between the vertical distributions of turbulent energy dissipation rate and fluorescence in the subsurface layer of four different oceanic settings, ranging from coastal to open sea and from temperate to polar. The microscale measurements of velocity shear and fluorescence are therefore connected to their macroscale distribution patterns. This allows us to explore alternative explanations for the observed fluorescence patterns based on previously reported interactions between turbulence and small-sized particles.

\section{MATERIALS AND METHODS}

The TurboMAP-L (Doubell et al. 2009) is a fastresponse conductivity, temperature, vertical shear and fluorescence probe capable of measuring at subcentimetre scales. This is a free-falling instrument with typical profiling speeds between 0.5 and $0.8 \mathrm{~m} \mathrm{~s}^{-1}$ and a sampling rate of $512 \mathrm{~Hz}$. Shear measurements from the TurboMAP-L are used to estimate dissipation rates of turbulent kinetic energy $\left(\varepsilon, \mathrm{m}^{2} \mathrm{~s}^{-3}\right)$ as:

$$
\varepsilon=(15 / 2) v \overline{(\partial u / \partial z}^{2}
$$

where $v$ is the kinematic viscosity of water $\left(v=10^{-6}\right.$ 


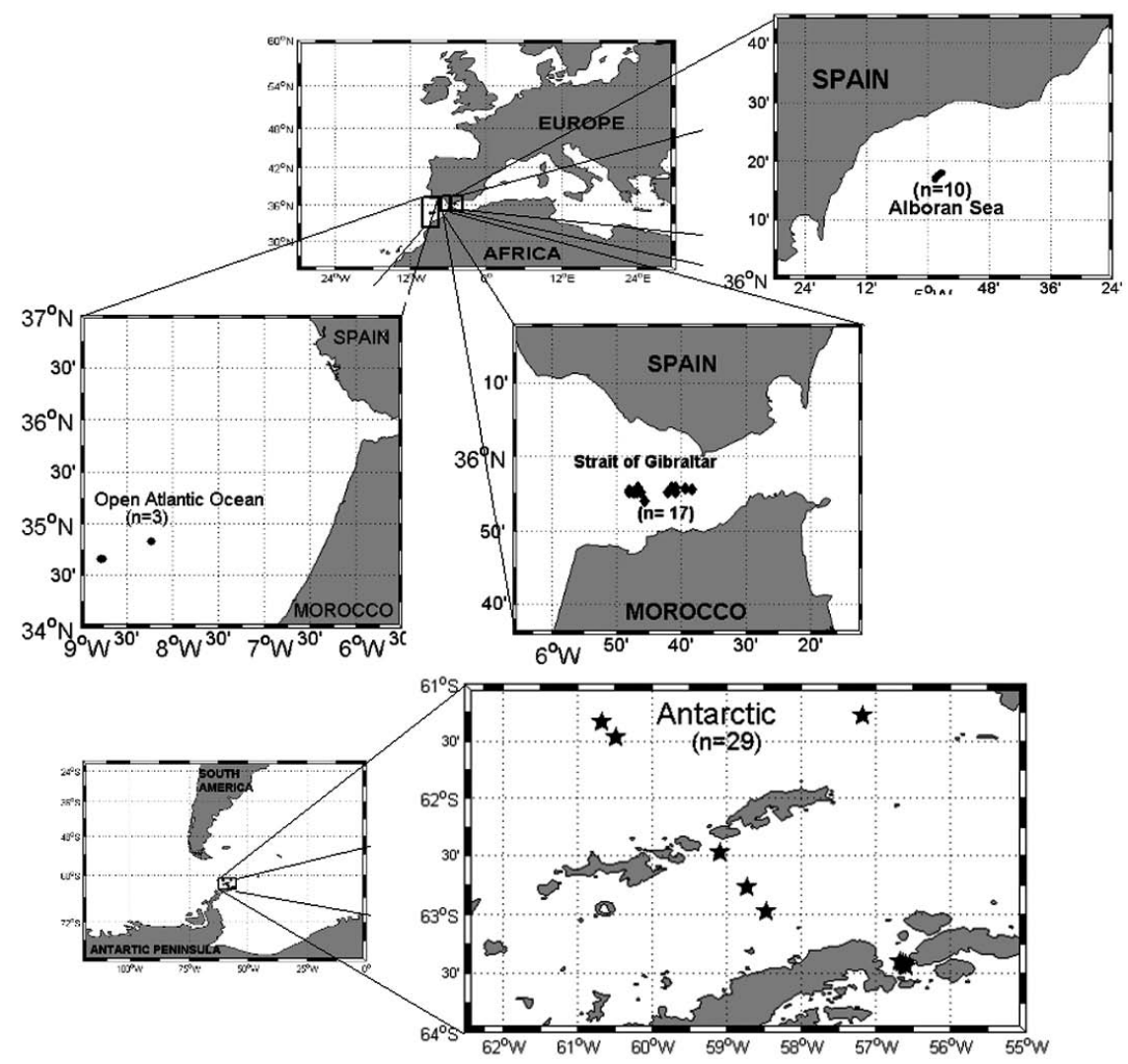

FIG. 1. - Position and number of profiles in the four study regions.

$\left.\mathrm{m}^{2} \mathrm{~s}^{-1}\right)$ and $\partial u / \partial z$ is the vertical velocity shear obtained directly from the TurboMAP measurements. The horizontal bar represents velocity shear averaging over 1-m intervals in order to eliminate the very high frequency variability in the data (following Tennekes and Lumley 1972 and Yamazaki et al. 2010).

A total of 64 TurboMAP profiles were collected in four different marine environments (Fig. 1): a coastal upwelling region (the Alboran Sea), a tidally-dominated system (the Strait of Gibraltar), an oligotrophic area (the open North Atlantic) and Antarctic waters. Each fluorescence profile, after smoothing to 1-metre averages, was fitted to a Gaussian curve as (Platt et al. 1988):

$F(z)=F_{0}+F_{\max } \exp \left[-\frac{\left(z-D C M_{\text {depth }}\right)^{2}}{D C M_{\text {thick }}^{2}}\right]$

where $F(z)$ is fluorescence as a function of depth $z$ and $F_{0}$ is the background fluorescence value. The data fitting provides the vertical position of the maximum fluorescence values $\left(D C M_{\text {depth }}\right)$, the relative value of this maximum over the background level $\left(F_{\max }\right)$ and the vertical thickness of the DCM ( $\left.D C M_{\text {thick }}\right)$ (left panels of Figs $2 \mathrm{a}$ and $2 \mathrm{~b}$, and Fig. S1). In addition, the relative fluorescence intensity was computed for each profile as $\left(F_{\text {max }}-F_{0}\right) / F_{\text {max }}$.

The same theoretical equation was applied to the $\varepsilon$ profiles, as a consistent feature of these profiles was the presence of isolated subsurface peaks of maximum $\varepsilon$ values (see examples in Fig. 2 and S1). The equation in this case is:

$$
\varepsilon(z)=\varepsilon_{0}+\varepsilon_{\max } \exp \left[-\frac{\left(z-\text { peak }_{\text {depth }}\right)^{2}}{\text { peak }_{\text {thick }}^{2}}\right]
$$

where $\varepsilon(z)$ is the turbulent energy dissipation rate as a function of depth $z$ and $\varepsilon_{0}$ is the background dissipation rate level. As for the fluorescence, data fitting to this expression provides the maximum $\varepsilon$ values at the subsurface $\left(\varepsilon_{\max }\right)$ and the position and vertical extent of the corresponding peak (peak $k_{\text {depth }}$ and peak $k_{\text {thick}}$, respectively). The presence of a subsurface $\varepsilon$ peak in the collected profiles may sometimes be connected to a vertical velocity shear maximum in the interior of the water column, as commonly observed in the Strait of Gibraltar and in the Alboran Sea (e.g. Bruno et al. 2002). However, some shallow subsurface peaks must be viewed with caution as they could be related to instrumental limitations of the TurboMAP. This probe is launched from the vessel and takes measurement while freely falling at a nearly constant speed through the water column. These conditions, are usually reached only after the instrument has descended down to a depth of 10-15 m. Therefore, the near-surface region where wind stress and wind waves cause high turbulence intensity may not be correctly sampled. Henceforth, $\varepsilon_{\max }$ located within the first 10-15 metres of the water column may actually correspond to maximum surface levels. 
a

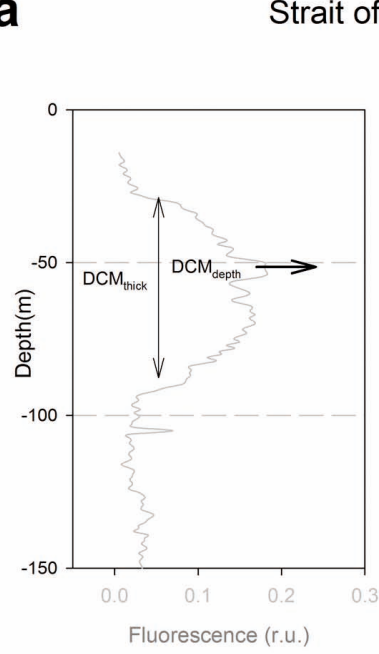

$\mathrm{Kv}\left(\mathrm{m}^{2} \mathrm{~s}^{-1}\right)$

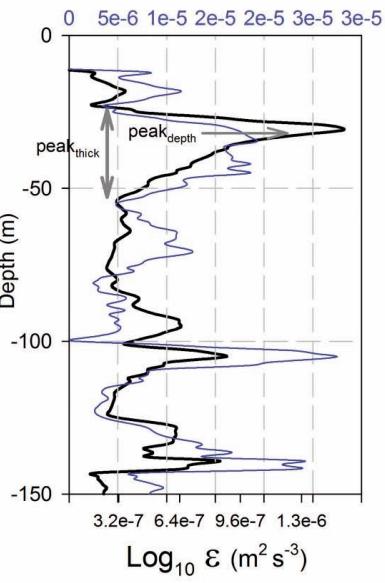

Antarctic

b

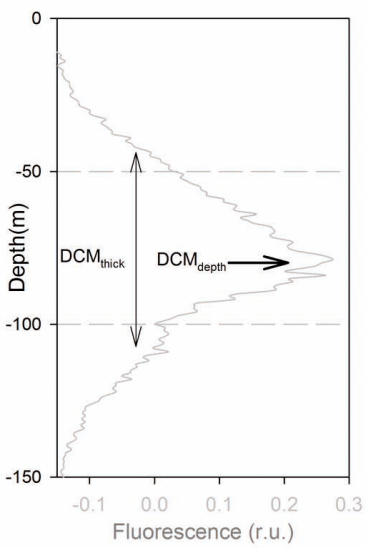

FIG. 2. - Analysis of selected fluorescence and $\varepsilon$ profiles. Left panels: fluorescence profile (grey line), $D C M_{\text {depth }}$ (black, thick arrow) and $D C M_{\text {thick }}$ (black, thin, double arrow) according to the Gaussian fit (Eq. 2). Right panels: $\varepsilon$ profiles (black line), peak ${ }_{\text {depth }}$ (grey, thick arrow) and peak $k_{\text {thick }}$ (grey, thin, double arrow) according to the Gaussian fit (Eq. 3). Right panels: $K_{v}$ profiles (blue lines) computed according to Equations 4 and 5.

We applied Equation (3) to all $\varepsilon$ profiles, 64 instances collected in four oceanic settings, and considered a "positive" profile when the goodness of fitting through Equation (3) was high $\left(r^{2}>0.5\right)$ and significant

$(\mathrm{p}<0.05)$ (see details in Table S1). The observed fluorescence distribution patterns may then be related to physical variables, such as vertical stratification and mixing characteristics of the water column, for each sampling site. Stratification is considered in terms of the squared buoyancy frequency $\left(N^{2}\right)$, defined as:

$$
N^{2}=-\frac{g}{\rho} \frac{\partial \rho}{\partial z}
$$

where $g$ is the gravity acceleration and $\rho$ is water density. High values of $N^{2}$ indicate a stratified portion of the water column, while low values are found in vertically homogeneous regions of the column.

The mixing intensity in a certain portion of the water column is represented by the vertical eddy diffusivity coefficient $\left(K_{v}\right)$ (e.g. Gregg et al. 2012). This coefficient has been computed in terms of the $\varepsilon$ measurements as (Osborn 1980):

$$
K_{v}=0.2 \frac{\varepsilon}{N^{2}}
$$

\section{RESULTS}

Most of the analysed $\varepsilon$ profiles ( $73.4 \%, 46$ profiles) showed the presence of a subsurface peak fulfilling the criteria defined in the Methods section (marked as positive in Table 1); they were most commonly found in the open ocean (100\% of analysed profiles) and in coastal regions (83-91\%) and were least prevalent in Antarctic waters (44.8\%).

In $67 \%$ of the positive profiles (31 profiles) the $D C M_{\text {depth }}$ was located at the base of the $\varepsilon$ subsurface maximum, within a distance less than peak thick $_{\text {(marked }}$ as match in Table 1) (Figs 2, 3a and S1). The scatter plot of $D C M_{\text {depth }}$ and peak $k_{\text {depth }}$ for all match profiles (Fig. 3a) shows a statistically significant and positive relationship, with the DCM being located around 18 $\mathrm{m}$ deeper than the $\varepsilon$ peaks. The relative fluorescence intensity in the match profiles was also positively correlated with the peak $k_{\text {thick }}$ (Fig. 3b); the thicker the turbulence peak the larger $\left(F_{\max }-F_{0}\right) / F_{\max }$.

The match profiles displayed a significant negative relationship between fluorescence and $\varepsilon$ in the region of the water column near $D C M_{\text {depth }}\left(D C M_{\text {depth }} \pm 0.5\right.$ $D C M_{\text {thick }}$ ) (Fig. 4), indicating that maximum fluorescence values were effectively associated with the mini-

TABLE 1. - Statistics of the analyses. "Positive" refers to $\varepsilon$ profiles which can be fitted to the Gaussian curve presented in Eq. 3 with $r^{2}>0.5$.

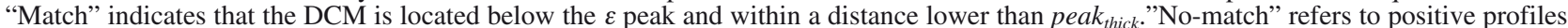
where the DCM position was not close to the $\varepsilon$ peak. The correlation coefficient corresponds to the relationship between $p e a k_{\text {depth }}$ and $D C M_{d e p t h}$ in each region (results showed in Fig. 3a).

\begin{tabular}{lccccc}
\hline Region & No. of analysed profiles & \% positives & \% match & \% no-match & $\mathrm{r}^{2}$ DCM $M_{\text {depth }}$ peak $_{\text {depth }}$ \\
\hline Alboran Sea & 12 & 83.3 & 66.6 & 33.4 & 0.7 \\
Strait of Gibraltar & 23 & 91.3 & 62.3 & 37.7 & 0.77 \\
Antarctic & 29 & 44.8 & 68.6 & 31.4 & 0.94 \\
Open ocean & 3 & 100 & 66.6 & 33.3 & $-*$ \\
Total & 64 & 73.4 & 67.6 & 32.4 & 0.91 \\
\hline
\end{tabular}

*only two profiles were marked as "match" 

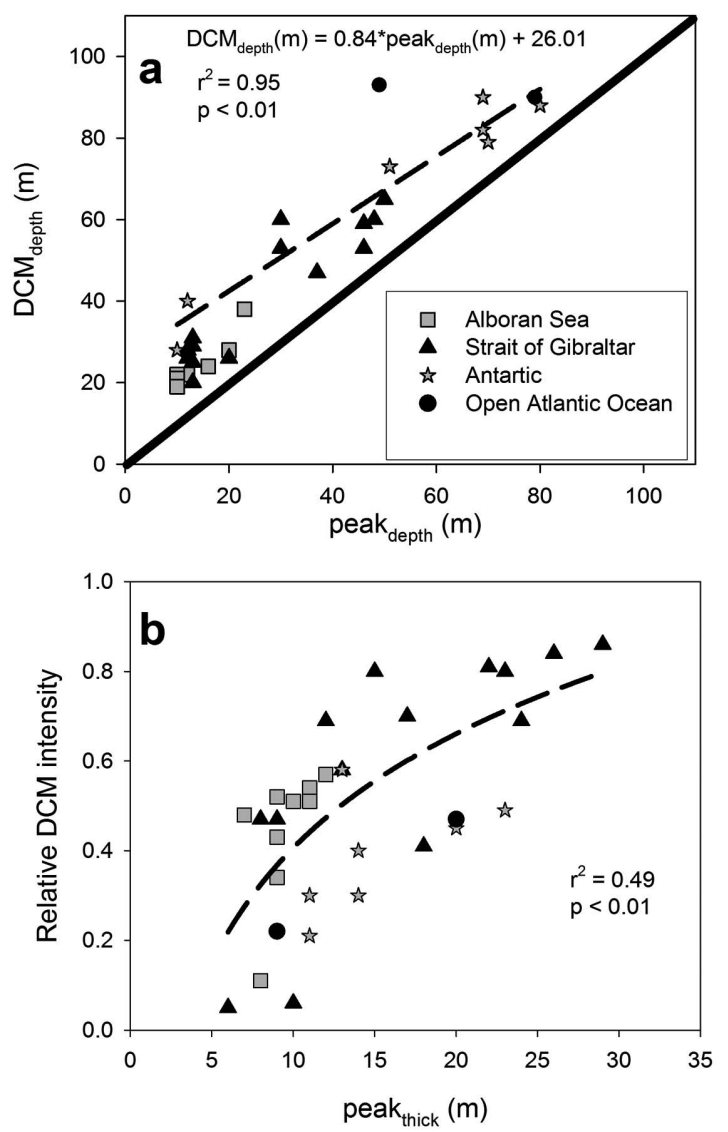

FIG. 3. - A, scatter plot of $D C M_{\text {depth }}$ as a function of peak ${ }_{\text {depth }}$. The bold black line represents the 1:1 relationship and the broken line the linear fit (equation inserted). B, scatter plot of relative fluorescence intensity at the DCM, defined as $\left(F_{\max }-F_{0}\right) / F_{\max }$, as a function of peak $k_{\text {thick}}$.

mum turbulence levels within the upper mixing layer. The coefficients of the correlation equations (Table 2) are quite consistent in all sampled areas, with a slope of around -0.1 and an intercept of almost -0.4 (one exception is the open Atlantic where only two profiles were considered as match, see Table 1), independently of the range of fluorescence levels, which is quite variable between sites. These inverse relationships between $\varepsilon$ and fluorescence were only found in the region of the DCM (i.e. within $D C M_{\text {depth }} \pm 0.5 D C M_{\text {thick }}$ ) and did not hold elsewhere in the water column.

DCMs were not associated with subsurface $\varepsilon$ gradients (no-match in Table 1) in approximately $33 \%$ of the positive profiles (14 profiles). In these cases stratification was high in the region of the water column occupied by the subsurface $\varepsilon$ peak (i.e. within $p e a k_{\text {depth }} \pm 0.5$

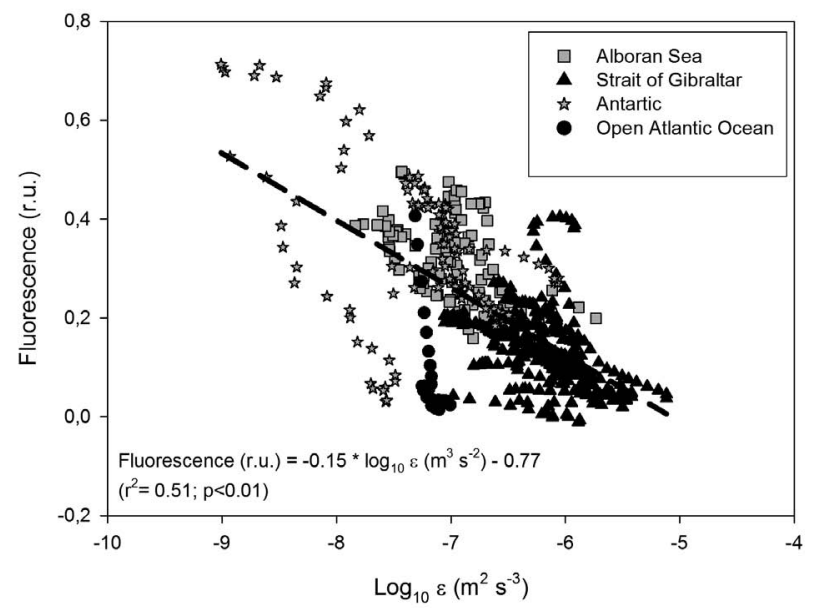

FIG. 4. - Scatter plot of fluorescence as a function of $\varepsilon$ for the match profiles in the $D C M_{\text {depth }} \pm 0.5 D C M_{\text {thick }}$ depth domain.

peak $_{\text {thick }}$ ) (mean $N^{2}=3.21 \times 10^{-3} \mathrm{~s}^{-1}$; s.d. $N^{2}=1.82 \times 10^{-3}$ $\left.\mathrm{s}^{-1} ; n=7\right)$. On the other hand, in the match profiles stratification was much weaker (mean $N^{2}=1.1 \times 10^{-3} \mathrm{~s}^{-1}$; s.d. $\left.N^{2}=1.2 \times 10^{-3} \mathrm{~s}^{-1} ; n=13\right)$ in the peak $k_{\text {depth }} \pm 0.5$ peak thick depth interval.

\section{DISCUSSION}

This study is not the first to report on phytoplankton accumulations in low shear portions of the water column (e.g. Estrada et al. 1993, Deksheniecks et al. 2001, Yamazaki et al. 2010) or below regions of enhanced mixing (Cullen and Eppley 1981, Abbott et al. 1984). However, to the best of our knowledge this is the first paper to describe the existence of a consistent relationship between the distributions of fluorescence and turbulent dissipation rate in a wide variety of oceanic settings, through the analysis of simultaneous high-resolution fluorescence and $\varepsilon$ profiles.

\section{Hypotheses to explain the observed patterns}

\section{Vertical variation of mixing intensity}

Most previous studies have discussed the inverse relationship between fluorescence and turbulence in terms of the vertical diffusive equation (e.g. Cowles et al. 1998, Mitchell et al. 2008, Prairie et al. 2011). Vertical diffusion has also been examined through a number of random-walk simulation models (e.g. Druet and Zieliński 1994, Dzierzbicka 2006, Ross 2006), although Visser (1997) warned about the need for a correct implementations of this technique. The key issue

TABLE 2. - Details of the $\varepsilon$-fluorescence relationships in each region and in the vicinity of the DCM as defined in the text; $* \mathrm{p}<0.01, * * \mathrm{p}<0.05$.

\begin{tabular}{lllc}
\hline Region & Season & Fluorescence $-\varepsilon$ relationship within $D C M_{\text {thick }}$ & $\mathrm{r}^{2}$ \\
\hline Elboran Sea & Late summer & Fluo $=-0.1 \log _{10} \varepsilon-0.38$ & $0.42^{*}$ \\
Strait of Gibraltar & Late summer & Fluo $=-0.08 \log _{10} \varepsilon-0.37$ & 101 \\
Antarctic & Austral summer & Fluo $=-0.11 \log _{10} \varepsilon-0.49$ & 300 \\
Open ocean & Spring & Fluo $=-0.76 \log _{10} \varepsilon-5.4$ & $0.35^{* *}$ \\
\hline
\end{tabular}


is how the vertical changes of the turbulent eddies may affect the vertical transport, and particularly the vertical convergence, of neutrally buoyant particles.

The intensity of turbulence is expressed in terms of the vertical eddy diffusion $\left(K_{v}\right)$ which, in weakly stratified regions like the surface mixed layer, is proportional to the rate of energy dissipation (Eq. 4 and Fig. 2). At the base of the mixed layer stratification increases and likely modulates turbulence and mixing, depending on other quantities that represent the flow dynamics such as vertical shear. The one-dimensional linearized form of the vertical diffusive equation, without any physical or biological source/sink term, is,

$$
\frac{\partial F}{\partial t}=\frac{\partial}{\partial z}\left(K_{v} \frac{\partial F}{\partial z}\right)=\frac{\partial K_{v}}{\partial z} \frac{\partial F}{\partial z}+K_{v} \frac{\partial^{2} F}{\partial z^{2}},
$$

The first term on the right hand side of this equation clearly illustrates the potentially principal role of the vertical and temporal dependence of $K_{v}$ on the vertical distribution of the fluorescence $F(z, t)$. In particular, Pelegrí and Sangrà (1998) have shown how the formation of layers with vertically homogeneous properties depends on the temporal memory of the turbulence, i.e. $K_{v}$ remaining high for some temporal characteristic scale even after the mechanism that led to the turbulence has ceased.

Changes in mixing intensity can also modify the nutrient flux at the $D C M_{\text {depth }}$ (Kiørboe 1993), potentially influencing its position and characteristics. However, our data clearly show that maximum $\varepsilon$ (and $K_{v}$ ) values are consistently observed above the $D C M_{\text {depth }}$ (Fig. 3a), while there is usually a negative vertical nutrient gradient within subsurface waters (Herbland and Voituriez 1976). Therefore, enhanced mixing associated with $\varepsilon$ maxima will hardly increase nutrient concentrations at the $D C M_{\text {depth }}$ when mixing is produced in shallow layers with low nutrient concentrations. We cannot, however, yet confirm this conjecture as no concurrent nutrient data is available for the field profiles.

\section{Modulation of cell sinking speed}

An alternative partial justification for the observed $\varepsilon$-fluorescence relationship patterns relies on the modulation of plankton sinking velocity by turbulent motion. Numerical modelling has shown that turbulence could enhance the sedimentation (flotation) velocities of heavy (light) particles (Wang and Maxey 1993, Yang and Lei 1998, Bosse et al. 2006, De Lillo et al. 2008). There are also several laboratory studies that examine how turbulence can modify the vertical velocity of small particles (Aliseda et al. 2002, Brucato et al. 1998, Ruiz et al. 2004, Ross 2006, Schimdt and Seuront 2008, Yang and Shy 2003, Zhou and Cheng 2009). Some studies show a reduction of the sedimentation velocity of synthetic particles in turbulent waters (e.g. Brucato et al. 1998, Zhou and Cheng 2009), while others report an increase in the natural tendency of the particles (to float or sink) in turbulent motion (e.g.,
Aliseda et al. 2002, Yang and Shy 2003, Ruiz et al. 2004, Schimdt and Seuront 2008).

Of all these previous studies, only the experiments by Ruiz et al. (2004) were conducted with real phytoplankton cells and using different turbulence generating devices. This study supported the hypothesis that turbulence increases the sedimentation velocity of natural plankton particles depending on the ratio between the Kolmogorov microscale and the particle's size. Thus, if cells sink faster in high-turbulence zones than in low-turbulence regions, then particles will accumulate in those low vorticity regions below the turbulence maximum (Fig. 5). Moreover, if this effect is happening in the oceanic mixing layer, it could also explain the positive relationship between peak $_{\text {thick }}$ and fluorescence relative intensity at the DCM (Fig. 3b). In relatively thick $\varepsilon$ maxima the velocity reduction happens along a greater fraction of the water column, potentially leading to higher accumulation at the $D C M_{\text {depth }}$.

Changes in sinking velocities have been classically attributed to cell buoyancy adjustments associated with environmental factors (Steele and Yentsh 1960, Gould 1988, Bienfang 1980) or to changes in seawater properties (density or dynamic viscosity). However, these physical changes would have a small effect on the settling particle velocity (a reduction of cell sinking speed of approximately $20 \%$ for a decrease of $10^{\circ} \mathrm{C}$ across the thermocline), suggesting that its impact on plankton vertical distribution is negligible (Ruiz 1996). The magnitude of changes in sinking velocity associated with changes in turbulent energy levels are much higher, up to one order of magnitude (Ruiz et al. 2004, Acuña et al. 2010), enough to alter the vertical plankton distribution (Lande and Wood 1987).

\section{Applicability/limitations of the hypotheses}

Since the significant inverse relationship between $\varepsilon$ and fluorescence (Fig. 4 and Table 2 ) is only valid for the vicinity of the DCM and not for the whole water column, none of the proposed interaction mechanisms may be responsible for DCM formation but rather for determining its precise vertical position (Fig. 5C). Further, it is very likely that none of the above proposed mechanisms controls alone the position and/or magnitude of DCM. Vertical changes in mixing intensity and sinking velocities will act together with other factors to shape the fluorescence profiles. Such factors will include the position of the nutricline, the light intensity field (e.g. Fig. 5A) and advective processes that bring different water masses in contact, as proposed in classic papers (e.g. Cullen 1982) and confirmed by modeling simulations (Hodges and Rudnick 2004, Huisman et al. 2006).

Our hypothesis is that DCM are created where appropriate physical and biological conditions exist (Cullen 1982), but turbulent motions lead to a continuous redistribution of the accumulated planktonic material (Fig. 5). This relocation of planktonic biomass may 


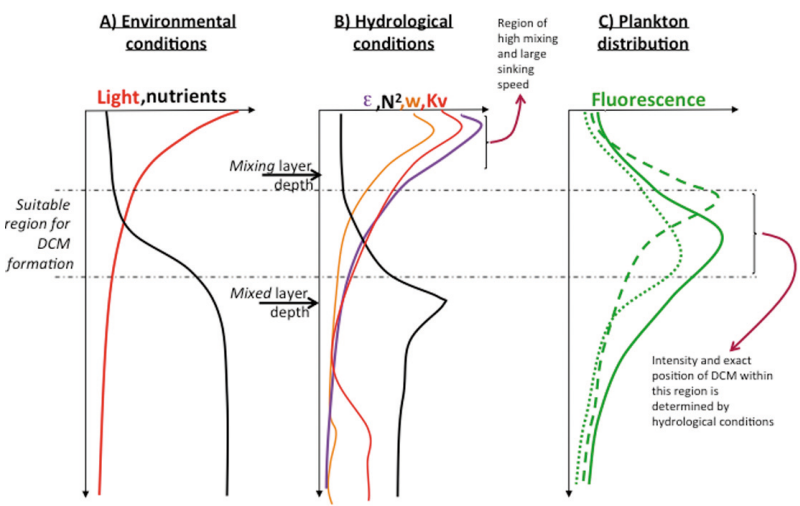

FIG. 5. - Principal mechanisms leading to the formation and vertical positioning of DCM. A) The typical light and nutrient distributions in the surface layer define a region where plankton accumulation is possible (enough light and sufficient nutrients). B) Surface mixing (for example by wind forcing) creates a "mixing" layer that is typically a fraction of the "mixed" layer and where mixing and sinking are high. C) Depending on the hydrodynamic characteristics, the DCM is found at different locations, always within the "optimal window" defined by light and nutrients.

only happen within the vertical limits determined by the physical-biological environment, defining an optimal window for DCM existence, mainly related to light and nutrient availability (Longhurst and Harrison 1989). Turbulence cannot move the DCM out of these limits, therefore explaining some of our discordant observations. For example, in a number of occasions with a positive profile (i.e., with an $\varepsilon$ peak fulfilling our classification criteria) the $D C M_{\text {depth }}$ did not coincide with peak $k_{\text {depth }}(17 \%$ of no-match, Table 1$)$, suggesting that there were additional mechanisms controlling the DCM position. It is noteworthy that in those profiles marked as no-match the $\varepsilon$ peak was located near a stratified region of the water column, while the match profiles occurred within the mixed layer and with weaker stratification. This would suggest that discontinuities in the water column (such as thermoclines and/or pycnoclines) can distort the redistribution of planktonic particles by turbulent motion. This supports the argument that, in addition to the characteristics of the turbulent field, there are a complex group of factors that partly control the position and characteristics of the DCM.

It is also necessary to consider here the different timescales of the turbulent field and the plankton distribution, as the former may change very rapidly while the latter requires relatively long times for significant changes to occur (Ruiz et al. 1996). Some of the no-match profiles may be related to these different reaction times, as the forcing processes need a minimum time to reach a steady state. Also, the scatter plot in Figure 3a (which includes only the match profiles) shows a relatively large dispersion $(95 \%$ confidence limits are around $\pm 13 \mathrm{~m}$ for the entire observational range), which could also be related to different reaction times. However, in specific oceanic settings and under certain atmospheric and hydrological conditions the $\varepsilon$ profiles may display very little variations (Carniel et al. 2012).
The proposed mechanisms for controlling DCM location and characteristics are only applicable if these DCM arise from a physical accumulation of phytoplankton cells (i.e. it corresponds to a DBM). In large areas of the subtropical and equatorial oceans, the position of the DCM does not coincide with the DBM (Zubkov et al. 2000, Perez et al. 2006) and results from physiological changes in the $\mathrm{Chl}$ : $\mathrm{C}$ ratio driven by photoadaptation processes (Falkowski 1998).

The dissociation between the position of the chlorophyll maximum and the biomass accumulation is typical of highly stratified and stable regions of the ocean (Longhurst and Harrison 1989), as may happen in late summer when the surface waters are well stratified and nutrient limited (Mann and Lazier 1991). This is not the case in the Strait of Gibraltar and the Alboran Sea, where the late-summer and early-fall DCM location coincides with a net rate of particulate carbon accumulation (Macías et al. 2008). Furthermore, in the region of the Antarctic Peninsula sampled here, chlorophyll concentration was found to be highly correlated with total microbial biomass throughout the entire austral summer (Karl et al. 1991).

The dissociation between DCM and DBM is most likely to occur when maximum fluorescence values appear below $80 \mathrm{~m}$ depth, as in our open Atlantic Ocean data. At these depths, light is a likely limiting factor and photoadaptation takes place. This could help explain why in this region the percentage of match profiles was lowest (Table 1) and why the coefficients of the linear relationship between fluorescence and $\varepsilon$ (Table 2) are substantially different from other regions.

Another potential source of error in our measurements is the use of in situ fluorescence as a proxy for chlorophyll as, because of photochemical quenching, the two variables are not always equivalent (Kolber and Falkowski 1991). However, concurrent measurements of fluorescence and in situ extracted chlorophyll have shown a high and significant correlation in both the Alboran Sea-Strait of Gibraltar region (RamírezRomero et al. 2012) and in Antarctic waters (Sangrà et al. submitted) when DCM are located below 10 $\mathrm{m}$ depth. No similar information is available for the open North Atlantic region but, as DCM are located here quite deep (typically below $80 \mathrm{~m}$, Fig. 3A), photochemical quenching is unlikely. Moreover, in spite of this possible limitation, the simultaneous sampling of both turbulence and fluorescence (as a proxy for phytoplankton abundance) represents a clear advantage to analyse and discuss the connections between turbulence and plankton distribution in the oceanic water column.

\section{CONCLUSIONS}

Our data suggest that turbulence is able to redistribute planktonic biomass once a subsurface accumulation (a DCM) is created within the upper layer of the ocean, if physical (e.g. stratification) and biological (e.g. light and 
nutrient) conditions are suitable. We have proposed two mechanisms to explain the observed pattern: (i) a vertically varying mixing intensity, with particles accumulating in low-mixing regions of the upper water column; and (ii) the modulation in the sinking speed of phytoplankton cells by turbulent motion, with cells concentrating under regions of enhanced sinking speeds. With the current data it is not possible to determine whether there is one single dominant effect or, on the contrary, both are taking place simultaneously in ocean waters. More field data and modeling simulations are necessary to further elucidate the exact interaction mechanisms.

The modulation of DCM characteristics through turbulence-particles interactions is a purely mechanical process leading to vertical changes in biomass concentration. For this to occur there have to be other processes, either biological (right light and nutrient conditions) or physical (water convergence), that provide for the increase in the available biomass. It could be reasonably argued that these other processes must also be important in shaping the vertical distribution of fluorescence, for example as a compromise between nutrient- and light-limited regions. However, the highly consistent relationship between the characteristics of the DCM and the vertical distribution of $\varepsilon$, frequently observed in the profiles of all four areas, indeed suggests a common mechanically-driven mechanism within the surface layers of the oceans.

\section{ACKNOWLEDGEMENTS}

E.R-R was supported by a grant from the Spanish FPU fellowship programme. Part of this work was written while PS was visiting the Department of Atmospheric and Oceanic Sciences of UCLA, with a Scholarship from the Spanish Government (Salvador de Madariaga, PR2010-0517). Data were collected as part of project FISIOCEAN (PIF2008-30F0061), funded by the Consejo Superior de Investigaciones Científicas, and the projects STRAIT (CTM2005-08142-C03-01 and CMT20080421) and COUPLING (CTM2008-06343-C02-01), both funded by the Spanish Science and Technology Ministry. We are very grateful to our two reviewers for providing many constructive and useful comments. Edward P. Morris helped with English editing.

\section{REFERENCES}

Acuña J.L., López-Alvarez M., Nogeira E., González-Taboada F. 2010. Diatom flotation at the onset of the spring phytoplankton bloom: an in situ experiment. Mar. Ecol. Prog. Ser. 400: 115-125.

Abbot M.R., Denman K.L., Powell T.M., Richerson P.J., Richards R.C., Goldman C.R. 1984. Mixing and the dynamics of the deep chlorophyll maximum in Lake Tahoe. Limnol. Oceanogr. 29: 862-878.

Abraham E.R. 1998. The generation of plankton patchiness by turbulent stirring. Nature 391: 577-580.

Aliseda A., Cartellier A., Hainaux F., Lasheras J.C. 2002. Effect of preferential concentration on the settling velocity of heavy particles in homogeneous isotropic turbulence. J. Fluid Mech. 468: 77-105.

Belyaev V.I. 1992. Modelling the influence of turbulence on phyto- plankton photosynthesis. Ecol. Model. 60: 11-29.

Bienfang P.K. 1980. Phytoplankton Sinking Rates in Oligotrophic Waters off Hawaii, USA. Mar. Biol. 61: 69-77.

Bosse T., Kleiser L., Miburg E. 2006. Small particles in homogeneous turbulence: Settling velocity enhancement by two-way coupling. Phys. Fluids 18: 027102.

Bowen J. D., Stolzenbach K. D., Chisholm S.W. 1993. Simulating bacterial clustering around phytoplankton cells in a turbulent ocean. Limnol. Oceanogr. 38: 36-51.

Brainerd K.E., Gregg M.C. 1995. Surface mixed and mixing layer depths. Deep-Sea Res. I 42(9): 1521-1543.

Brucato A., Grisafi F., Montante G. 1998. Particle drag coefficients in turbulent fluids. Chem. Eng. Sci. 53: 3295-3314.

Bruno M., Alonso J.J., Cozar A., Vidal J., Ruiz-Canavate A., Echevarria F., Ruiz J. 2002. The boiling water phenomena at Camarinal Sill, the Strait of Gibraltar. Deep-Sea Res. II 49: 4097-4113.

Carniel S., Kantha L.H., Book J.W., Sclavo M., Prandke H. 2012. Turbulence variability in the upper layers of the Southern Adriatic Sea under a variety of atmospheric forcings conditions. Cont. Shelf Res. 44: 39-56.

Cowles T.J., Desiderio R.A., Carr M.-E. 1998. Small-scale planktonic structure: Persistence and trophic consequences. Oceanogr. 11: 4-9.

Cullen J.J., Eppley R.W. 1981. Chlorophyll maximum layers of the Southern California Bight and possible mechanisms of their formation and maintenance. Oceanol. Acta 4: 23-32.

Cullen J.J. 1982. The deep chlorophyll maximum: comparing vertical profiles of chlorophyll a. Can. J. Fish. Aqua. Sci. 39: 791-803.

Cullen J.J., Lewis M.R. 1988. The kinetics of algal photoadaptation in the context of vertical mixing. J. Plank. Res. 10(5): 1039-1063.

D’Ovidio F., De Monte S., Alvain S., Dondonneau Y., Lévy M. 2010. Fluid dynamical niches of phytoplankton types. Proc. Natl. Acad. Sci. USA 107: 18366-18370.

De Lillo F., Cecconi F., Lacorata G., Vulpiani A. 2008. Sedimentation speed of inertial particles in laminar and turbulent flows. EPL 84: 40005.

Deksheniecks M.M., Donaghay P.L., Sullivan J.M., Rines J.E.B., Osborn T.R., Twardowski M.S. 2001. Temporal and spatial occurrence of thin phytoplankton layers in relation to physical processes. Mar. Ecol. Prog. Ser. 223: 61-71.

Doubell M.J., Yamazaki H., Li H., Kokuby Y. 2009. An advanced laser-based fluorescence microstructure profiler (TurboMAPL) for measuring bio-physical coupling in aquatic systems. $J$. Plank. Res. 31: 1441-1452.

Druet C., Zielinski A. 1994. Modelling the fine-structure of the phytoplankton concentration in a stable stratified sea. Oceanol. Acta 17: 79-88.

Dzierzbicka L. 2006. Effects of turbulent mixing on the marine plankton vertical distribution: model simulations. Polish J. Ecol. 54: 215-230.

Estrada M., Marrase C., Latasa M., Berdalet E., Delgado M., Riera T. 1993. Variability of the Deep Chlorophyll Maximum characteristics in the northwestern Mediterranean. Mar. Ecol. Prog. Ser. 92: 289-300.

Falkowski P.G. 1998. Light-shade adaptation in marine phytoplankton. In: Falkowski P.G. (ed.), Primary productivity in the sea. Plenum Press, pp. 99-119.

Falkowski P.G., Barber R., Smetacek V. 1998. Biogeochemical controls and feedbacks on ocean primary production. Science 281: 200-206.

Falkowski P.G., Oliver M.J. 2007. Mix and match: how climate selects phytoplankton. Nature Rev. Microb. 5: 813-819.

Fasham M.J.R., Platt T., Irwin B., Jones K. 1985. Factors Affecting the Spatial Pattern of the Deep Chlorophyll Maximum in the Region of the Azores Front. Prog. Oceanogr. 14: 129-165.

Fennel K., Boss E. 2003. Subsurface maxima of phytoplankton and chlorophyll, Steady-state solutions from a simple model. Limnol. Oceanogr. 48: 1521-1534.

Franks P.J.S. 2005. Plankton patchiness, turbulent transport and spatial spectra. Mar. Ecol. Prog. Ser. 294: 295-309.

Gould R.W. 1988. Net phytoplankton in a Gulf Stream warm-core ring: species composition, relative abundance, and the chlorophyll maximum layer. Deep-Sea Res. 35: 1595-1614.

Gregg M.C., Alford M.H., Kontoyiannis H., Zervakis V., Winkel D. 2012. Mixing over the steep side of the Cycladic Plateau in the 
Aegean Sea. J. Mar. Syst. 89: 30-47.

Herbland A., Voituriez B. 1979. Hydrological structure analysis for estimating the primary production in the tropical Atlantic Ocean. J. Mar. Res. 37: 87-101.

Hodges B.A., Rudnick D.L. 2004. Simple models of steady deep maxima in chlorophyll and biomass. Deep-Sea Res. I 51: 999-1015.

Husiman J., Pham-Ti N.N., Karl D.M., Sommeijer B. 2006. Reduced mixing generates oscillations and chaos in the oceanic deep chlorophyll maximum. Nature 439(7074): 322-325.

Jassby A., Powell T.M. 1975. Vertical patterns of eddy diffusion during stratification in Castle Lake, California. Limnol. Oceanogr. 20: 530-543.

Jumars P.A., Trowbrige J.H., Boss E., Karp-Boss L. 2009. Turbulenceplankton interactions: a new cartoon. Mar. Ecol. 30: 133-150.

Karl D.M., Holm-Hasen O., Taylor G.T., Tien G., Bird D.F. 1991. Microbial biomass and productivity in the western Bransfield Strait, Antarctica during the 1986-87 austral summer. Deep-Sea Res. II 38: 1029-1055.

Kiørboe, T. 1993. Turbulence, phytoplankton cell size, and the structure of pelagic food webs. Adv. Mar. Biol. 29: 1-72.

Kolber, Z. Falkowski, P.G. 1993. Use of active fluorescence to estimate phytoplankton photosynthesis in situ. Limnol. Oceanogr. 38(8): 1646-1665.

Kolmogorov A.N. 1941. The local structure of turbulence in incompressible viscous fluid for very large Reynolds numbers. Proc. USSR Acad. Sci. 30: 299-303.

Lande R., Wood M. 1987. Suspension times of particles in the upper ocean. Deep-Sea Res. 34: 61-72.

Lazier J.R.N., Mann K.H. 1989. Turbulence and the diffusive layers around small organisms. Deep-Sea Res. 36: 1721-1733.

Lewis M.R., Horne E.P.W., Cullen J.J., Oakey N.S., Platt T. 1984 Turbulent motions may control phytoplankton photosynthesis in the upper ocean. Nature 311: 49-50.

Longhurst A., Harrison A. 1989. The biological pump: profiles of plankton production and consumption in the upper ocean. Prog. Oceanogr. 22: 47-123.

Macías D., Lubian L.M., Echevarría F., Huertas E., García C.M. 2008. Chlorophyll maxima and water mass interfaces: tidally induced dynamics in the Strait of Gibraltar. Deep-Sea Res. I 55: 832-846.

Mann K.H., Lazier J.R.N. 1991. Dynamics of marine ecosystems. Biological-Physical Interactions in the Oceans. Blackwell Scientific Publications.

Margalef R. 1978. Life-forms of phytoplankton as survival alternatives in an unstable environment. Oceanol. Acta 1: 493-509.

Mitchell J.G., Yamazaki H., Seuront L., Wolk F., Li H. 2008. Phytoplankton patch patterns: Seascape anatomy in a turbulent ocean. J. Mar. Sys. 69: 247-253.

Osborn T.R. 1980. Estimates of the local rate of vertical diffusion from dissipation measurements. J. Phys. Oceanogr. 10: 83-89.

Pérez V., Fernández E., Marañón E., Morán X.A.G., Zubkov M.V. 2006. Vertical distribution of phytoplankton biomass, production and growth in the Atlantic subtropical gyres. Deep-Sea Res. I 53: 1616-1634.

Pelegrí J.L., Sangrà P. 1998. A mechanism for layer formation in stratified geophysical flows. J. Geophys. Res. 103: 30679-30693.

Platt T. 1972. Local phytoplankton abundance and turbulence. $J$. Plank. Res. 19: 183-187.

Platt T., Sathyendranath S., Caverhill C., Lewis M.R. 1988. Ocean primary production and available light: further algorithms for remote sensing. Deep-Sea Res. 35: 855-879.

Prairie J.C., Franks P.J.S., Jaffe J.S., Doubell M.J., Yamazaki H. 2011. Physical and biological controls of vertical gradients in phytoplankton. Limnol. Oceanogr. Fluids Environ. 1: 75-90.

Ramirez-Romero, E., Macias, D., Bruno, M., Reyes, E., Navarro, G., Garcia, C.M. 2012. Submesoscale, tidally-induced biogeochemical patterns in the Strait of Gibraltar. Estuar. Coast. Shelf Sci. 101: 24-32.

Riley G.A., Stomnel H., Bumpus D.F. 1949. Quantitative ecology of the plankton of the Western North Atlantic. Bull. Bingharn Oceanogr. Coll. 12: 1-169.

Ross O.N. 2006. Particles in motion: How turbulence affects plank- ton sedimentation from an oceanic mixed layer. Geophys. Res. Let. 33: L10609.

Rothschild B.J., Osborn T.R. 1988. Small-scale turbulence and plankton contact rates. J. Plank. Res. 10: 465-474.

Ruiz J., García C.M., Rodríguez J. 1996. Sedimentation loss of phytoplankton cells from the mixed layer: effects of turbulence levels. J. Plank. Res. 18: 1727-1734.

Ruiz J. 1996. The role of turbulence in the sedimentation loss of pelagic aggregates from the mixed layer. J. Mar. Res. 54: 385-406.

Ruiz J., Macías D., Peters F. 2004. Turbulence increases the average settling velocity of phytoplankton cells. Proc. Natl. Acad. Sci. USA 101: 17720-17724.

Sangrà, P., Garcia-Muñoz, C., Garcia, C.M., Marrero-Diaz, A., Sobrino, C., Mouriño-Carballido, B., Aguiar-Gonzalez, B., Henriquez-Pastene, C., Rodriguez-Santana, A., Lubian, L.M., Hernandez-Arencibia, M., Hernandez-Leon, S., Vazquez, E., Estrada-Allis, S.N. Coupling between the upper ocean layer variability and size-fractioned phytoplankton in a no nutrient limited environment. Mar. Ecol. Prog. Ser. Submitted

Seuront L., Lagadeuc Y. 1997. Characterization of space-time variability in stratified and mixed coastal waters (Baie des Chaleurs, Quebec, Canada): application of fractal theory. Mar. Ecol. Prog. Ser. 159: 81-95.

Steele J.H., Yentsch C.S. 1960. The vertical distribution of chlorophyll. J. Exp. Mar. Biol. Ecol. 39: 217-226.

Tennekes H., Lumley J.L. 1972. A First Course in Turbulence. Massachussetts Institute of Technology.

Visser A.W. 1997. Using random walk models to simulate the vertical distribution of particles in a turbulent water column. Mar. Ecol. Progr. Ser. 158: 275-281.

Wang L.P., Maxey M.R. 1993. Settling velocity and concentration distribution of heavy particles in homogeneous isotropic turbulence. J. Fluid. Mech. 256: 27-68.

Wolk F., Yamazaki H., Seuront L., Lueck R.G. 2002. A New FreeFall Profiler for Measuring Biophysical Microstructure. J. Atmos. Ocean Tech. 19: 780-793.

Yamazaki H., Mitchell J.G., Seuront L., Wolk F., Li H. 2006. Phytoplankton microstructure in fully developed oceanic turbulence. Geophys. Res. Lett. 33: L01603.

Yamazaki H., Honma H., Nagai T., Doubell M.J., Amakasu K., Kumagai M. 2010. Multilayer biological structure and mixing in the upper water column of Lake Biwa during summer 2008. Limnology 11: 63-70.

Yang C.Y., Lei U. 1998. The role of the turbulent scales in the settling velocity of heavy particles in homogeneous isotropic turbulence. J. Fluid Mech. 371: 179-205.

Yang T.S., Shy S.S. 2003. The settling velocity of heavy particles in an aqueous near-isotropic turbulence. Phys. Fluids 15: 868-880.

Zhou Q., Cheng N.S. 2009. Experimental investigation of single particle settling in turbulence generated by oscillating grid. Chem. Eng. J. 149: 289-300.

Zubkov M.V., Sleigh M.A., Burkill P., Leakey R.J.G. 2000. Picoplankton community structure on the Atlantic Meridional Transect: a comparison between seasons. Prog. Oceanogr. 45: 369-386.

Scient. ed.: X.A. Álvarez-Salgado

Received March 22, 2013. Accepted September 6, 2013.

Published online October 3, 2013.

\section{SUPPLEMENTARY MATERIAL}

The following material is available through the web page http://www.icm.csic.es/scimar/supplm/sm03854SMA.pdf

FIG. S1. - Profiles from the Turbomap at each station marked as 'match' according to the main text. Left panel, fluorescence (green line) and adjusted profile (blue line) following Equation 2. Right panel, $\varepsilon$ (black line) and adjusted profile (red line) following Equation 3. Parameters of adjustment are show in Table S1.

TABLE S1. - Position of each 'match' profile and values of the statistical adjustment of the fluorescence and $\varepsilon$ profile according to Equations 2 and 3 respectively. 


\section{Turbulence as a driver for vertical plankton distribution in the subsurface upper ocean}

DIEGO MACÍAS , ÁNGEL RODRÍGUEZ-SANTANA, EDUARDO

RAMÍREZ-ROMERO, MIGUEL BRUNO, JOSEP L. PELEGRÍ, PABLO SANGRÀ, BORJA AGUIAR-GONZÁLEZ and CARLOS M. GARCÍA

Supplementary material 
S2 • D. Macias et al.
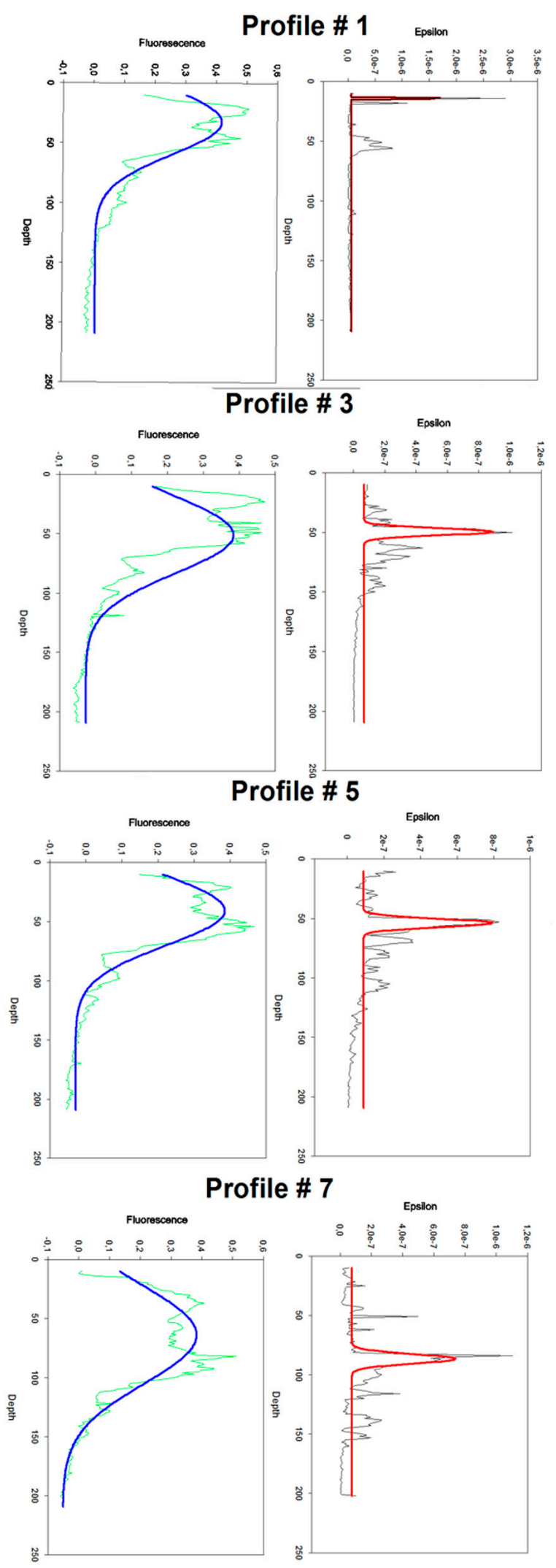

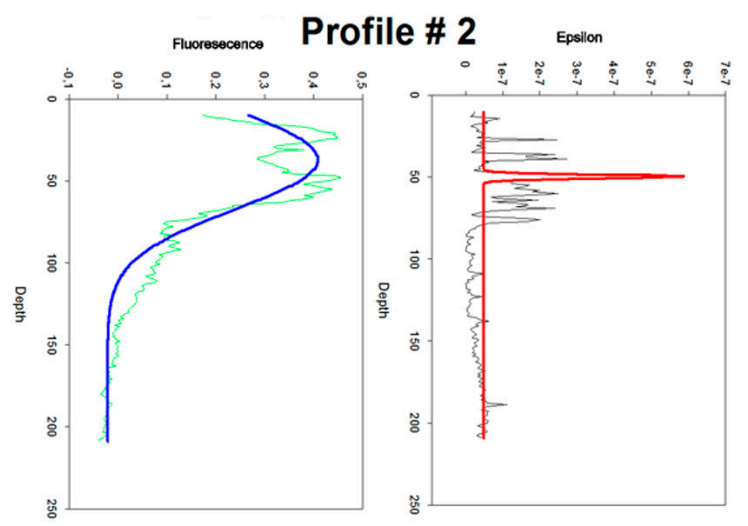

Profile \# 4
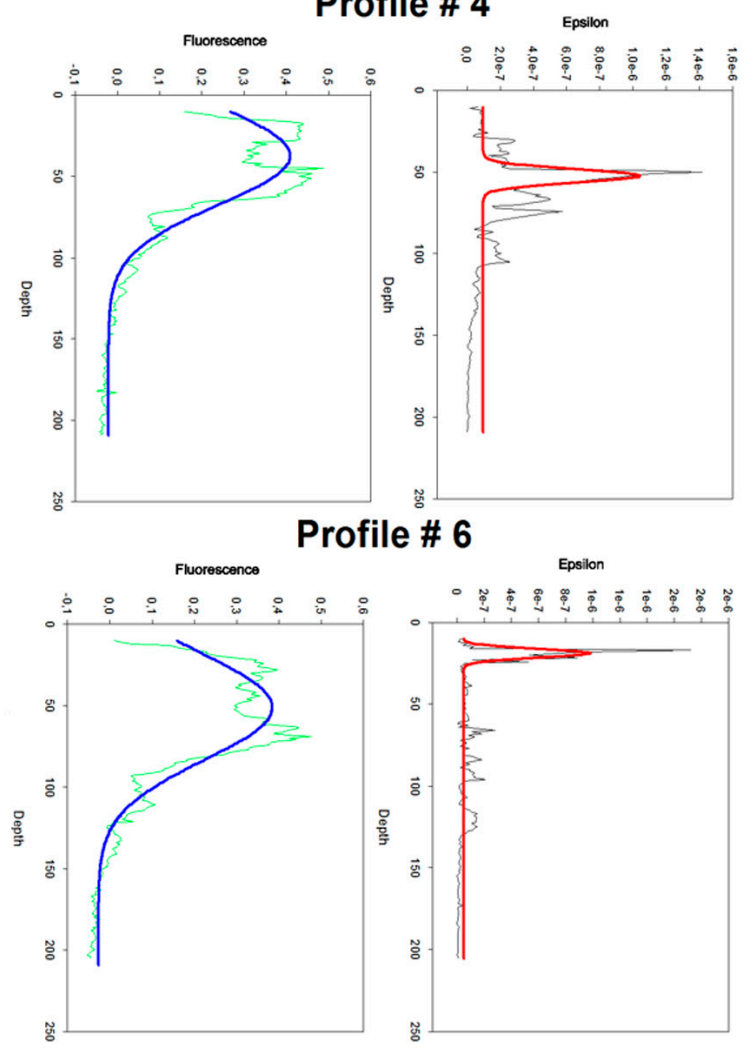

Profile \# 8

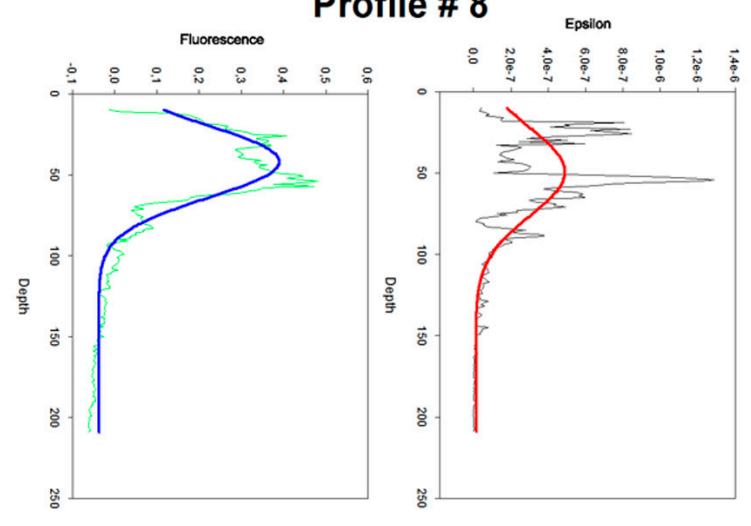

FIG. S1. - Profiles from the Turbomap at each station marked as 'match' according to the main text. Left panel, fluorescence (Green line) adjusted profile (blue line) following Equation 2. Right panel, epsilon (black line) and adjusted profile (red line) following Equation 3. Parameters of adjustment are show in Table S1.

SCI. MAR., 77(4), December 2013, S1-S6. ISSN 0214-8358 doi: 10.3989/scimar.03854.03S 
Profile \# 9

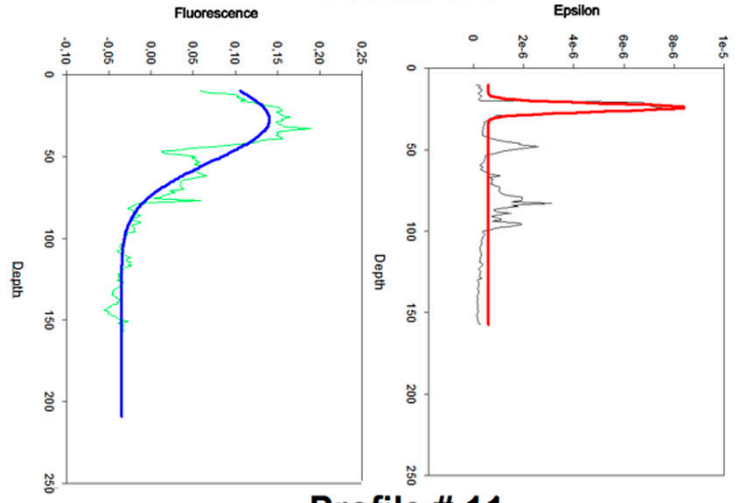

Profile \# 11

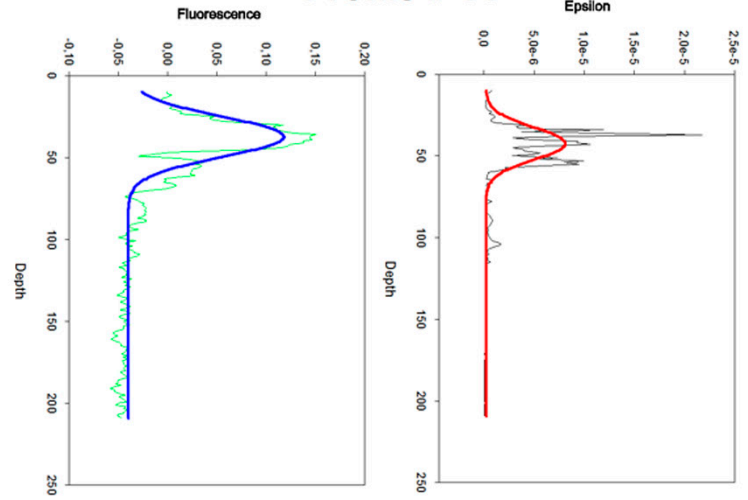

Profile \# 13

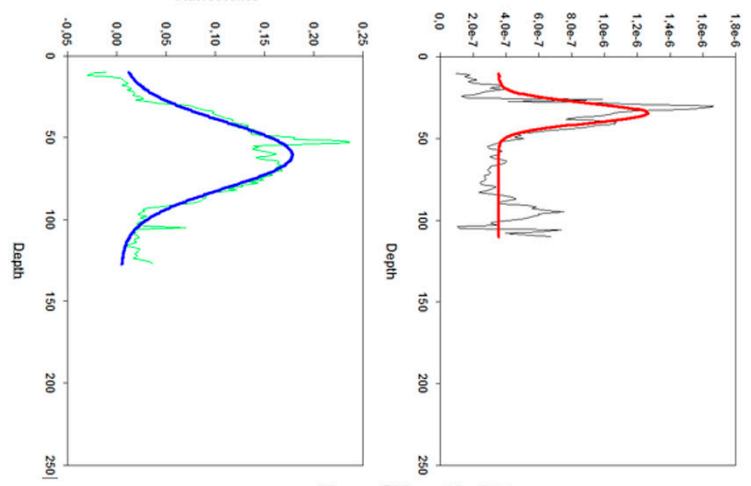

Profile \# 15

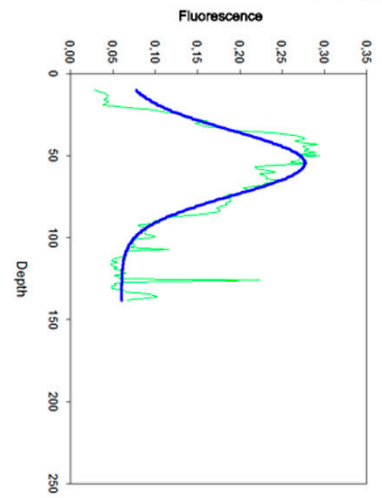

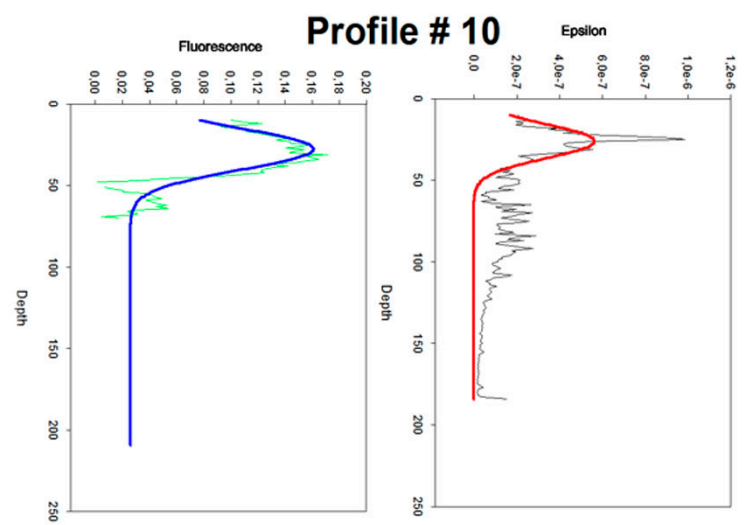

Profile \# 12

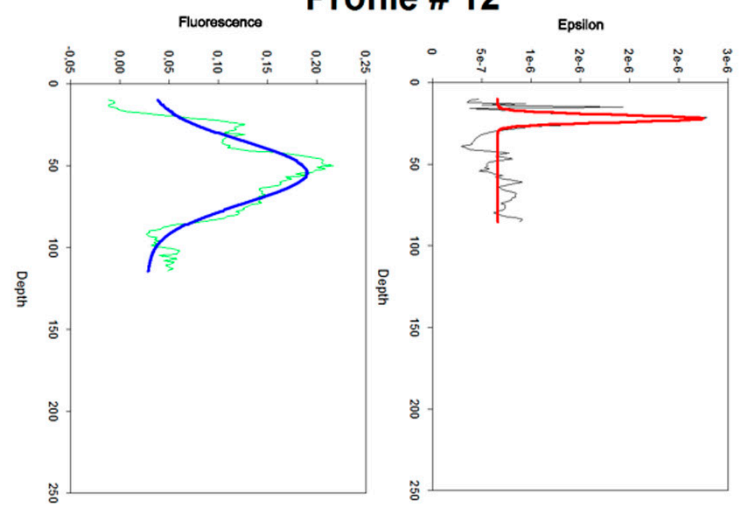

Profile \# 14

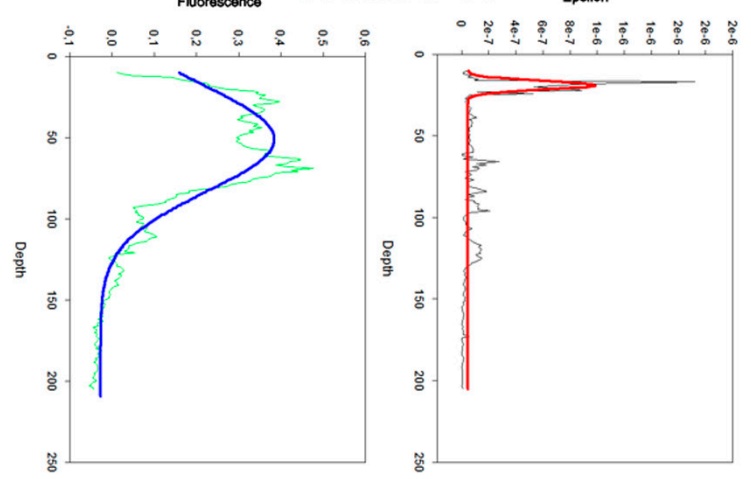

Profile \# 16

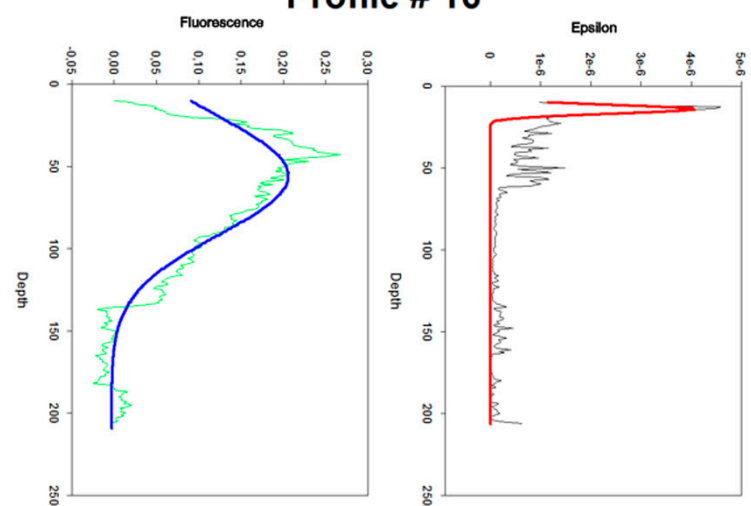

FIG. S1 (cont.). - Profiles from the Turbomap at each station marked as 'match' according to the main text. Left panel, fluorescence (Green line) adjusted profile (blue line) following Equation 2. Right panel, epsilon (black line) and adjusted profile (red line) following Equation 3. Parameters of adjustment are show in Table S1. 
S4 - D. Macias et al.
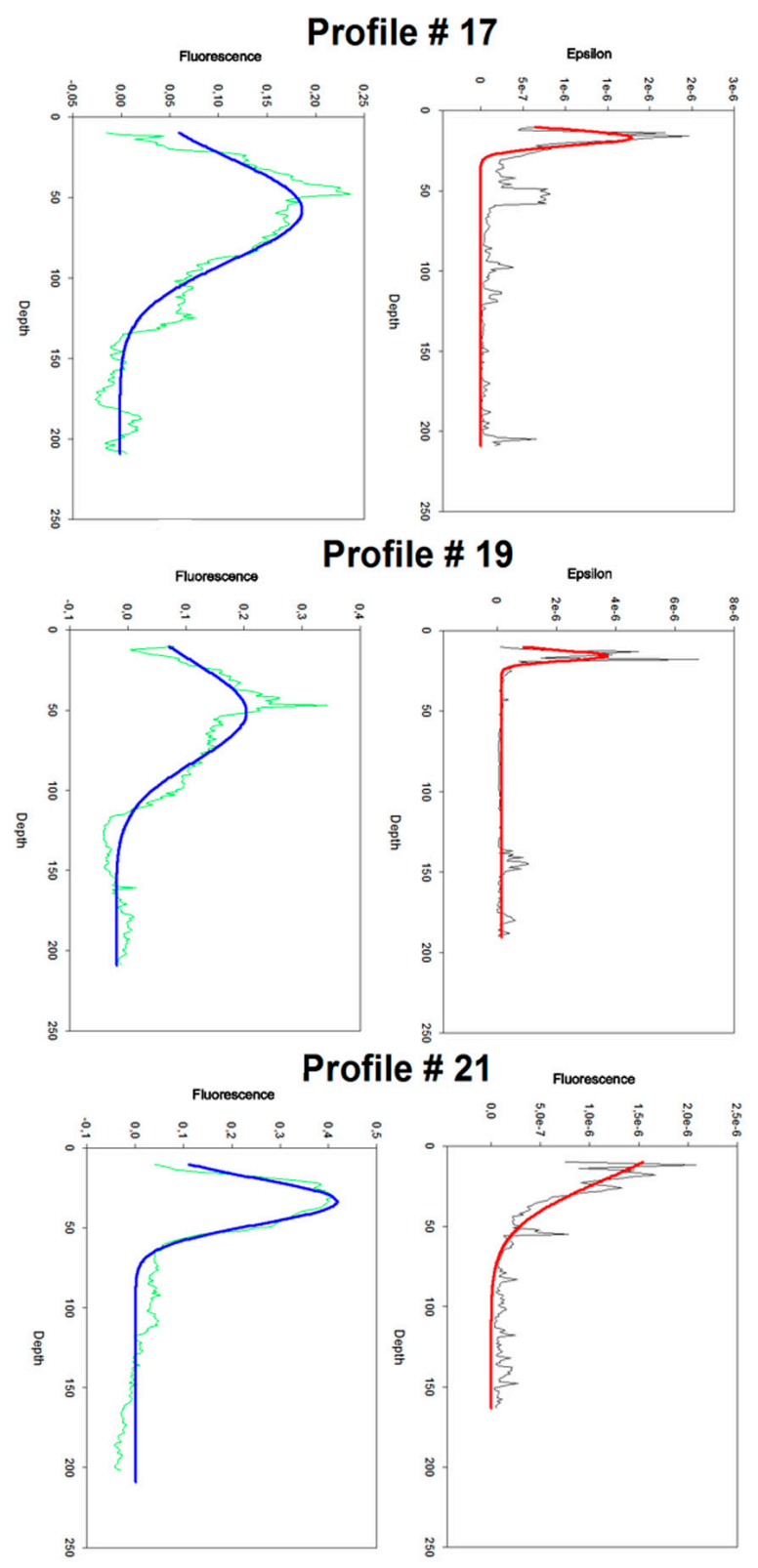

Profile \# 23

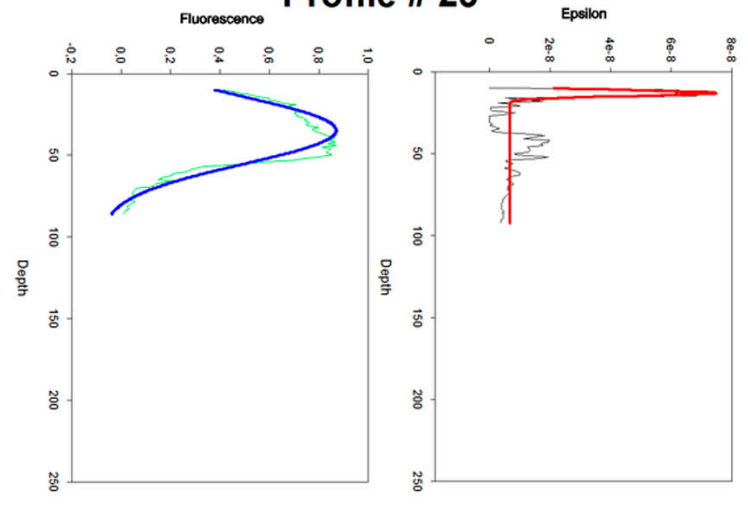

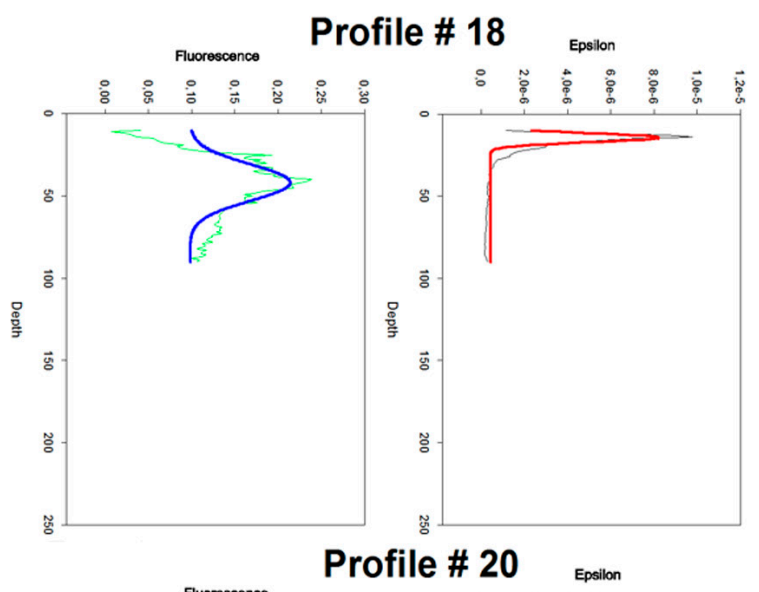
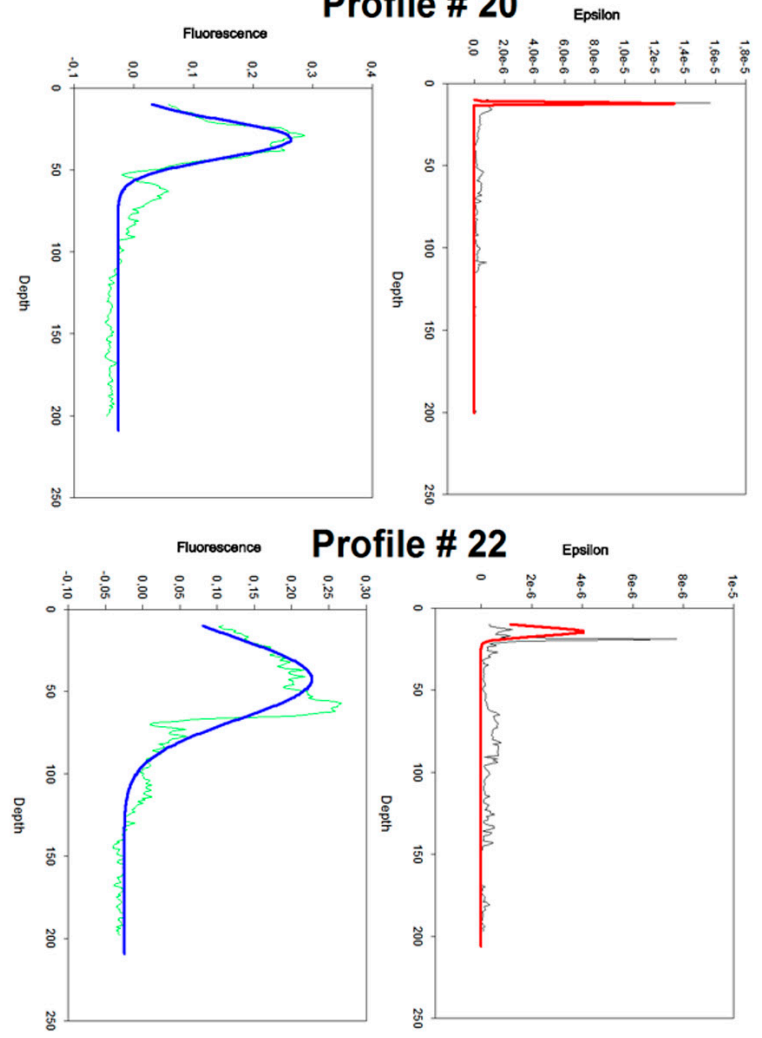

Profile \# 24

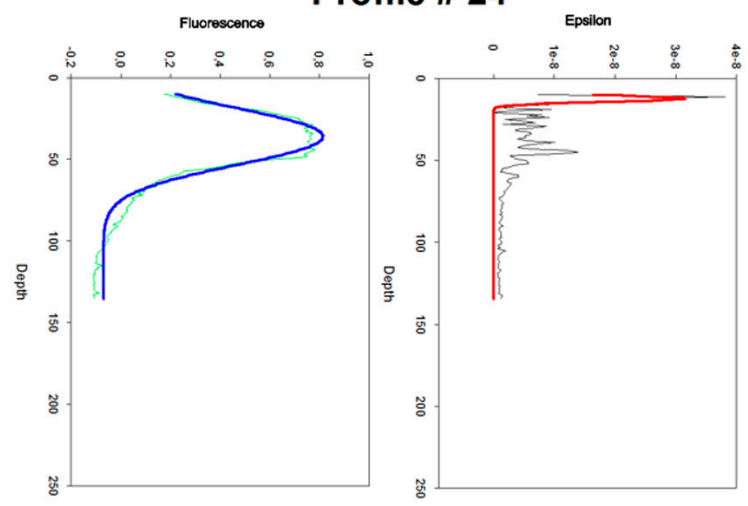

FIG. S1 (cont.). - Profiles from the Turbomap at each station marked as 'match' according to the main text. Left panel, fluorescence (Green line) adjusted profile (blue line) following Equation 2. Right panel, epsilon (black line) and adjusted profile (red line) following Equation 3. Parameters of adjustment are show in Table S1.

SCI. MAR., 77(4), December 2013, S1-S6. ISSN 0214-8358 doi: 10.3989/scimar.03854.03S 
Profile \# 25

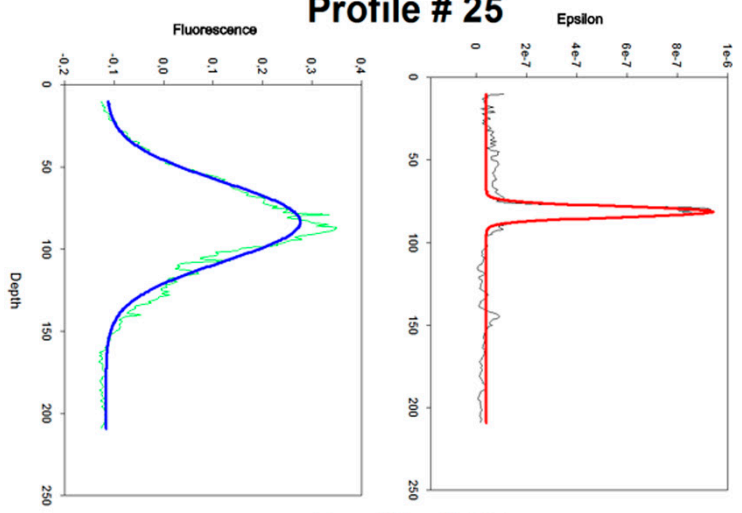

Profile \# 27 Epsion

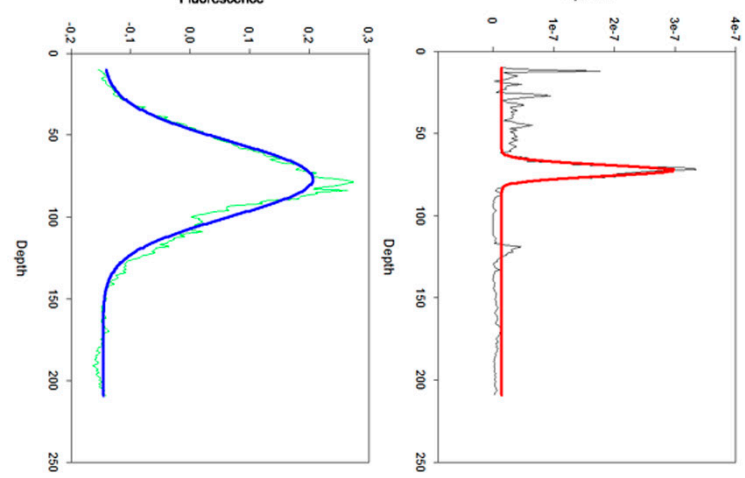

Profile \# 29

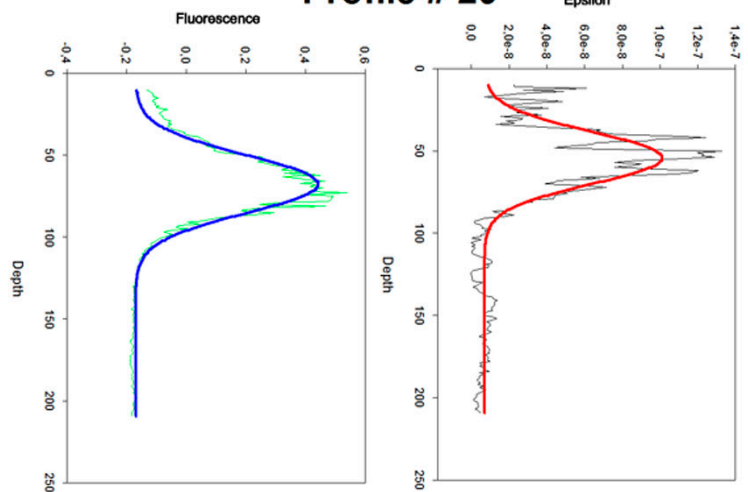

Profile \# 31

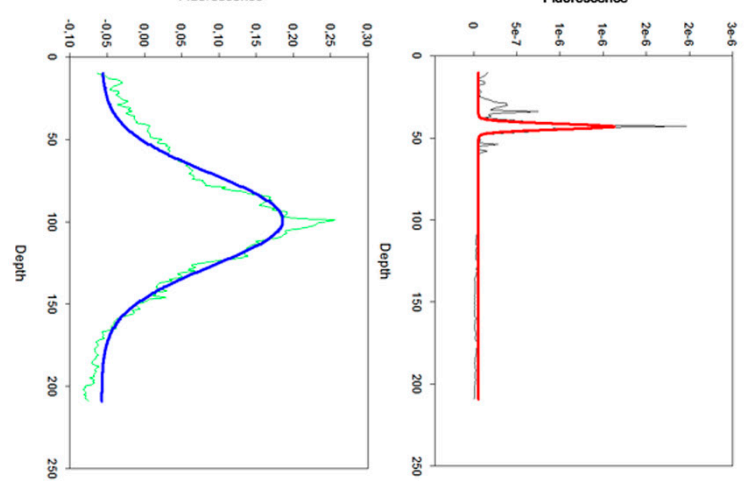

Profile \# 26
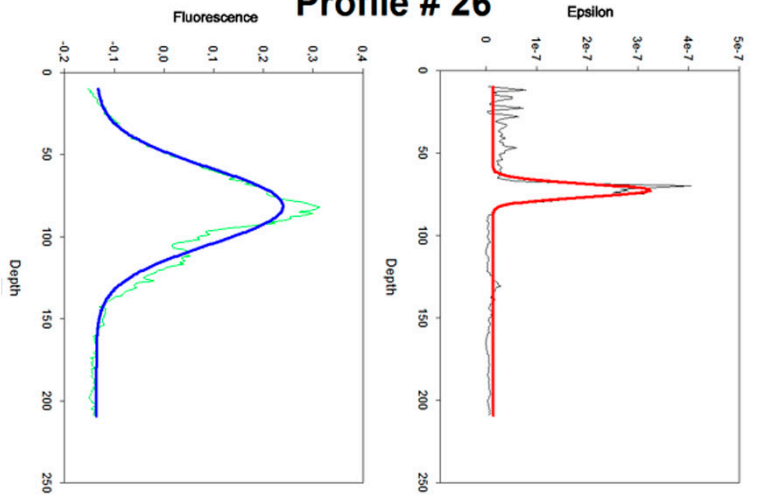

Profile \# 28

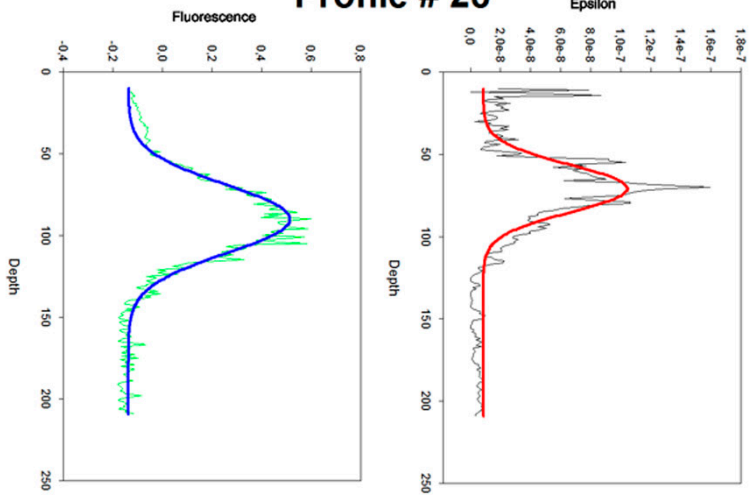

Profile \# 30

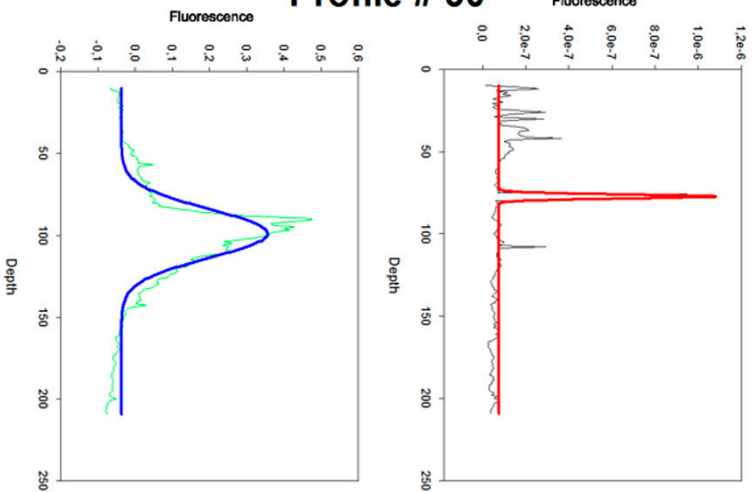

FIG. S1 (cont.). - Profiles from the Turbomap at each station marked as 'match' according to the main text. Left panel, fluorescence (Green line) adjusted profile (blue line) following Equation 2. Right panel, epsilon (black line) and adjusted profile (red line) following Equation 3. Parameters of adjustment are show in Table S1. 
S6 - D. Macías et al.

TABLE S1. - Position of each 'match' profile and values of the statistical adjustment of the fluorescence and epsilon profile according to Equations 2 and 3 respectively.

\begin{tabular}{|c|c|c|c|c|c|c|c|c|c|c|c|}
\hline \multirow[b]{2}{*}{ Profile \# } & \multirow[b]{2}{*}{ Zone } & \multirow[b]{2}{*}{ Latitude } & \multirow[b]{2}{*}{ Longitude } & \multicolumn{4}{|c|}{ Fluorescence profile } & \multicolumn{4}{|c|}{$\varepsilon$ profile } \\
\hline & & & & $\mathrm{DCM}_{\max }$ & $\mathrm{DCM}_{\text {thick }}$ & $\mathrm{DCM}_{\text {depth }}$ & $\mathrm{r}^{2}$ & $\mathrm{e}_{\max }$ & e_peak ${ }_{\text {thick }}$ & e_peak ${ }_{\text {depth }}$ & $\mathrm{r}^{2}$ \\
\hline 1 & Alb. Sea & 36.28 & -4.978 & 0.41 & 32.23 & 27.4 & 0.91 & $4.8 \mathrm{e}^{-6}$ & 25.6 & 14.27 & 0.68 \\
\hline 2 & Alb. Sea & 36.29 & -4.977 & 0.39 & 32.8 & 37.4 & 0.92 & $5.3 \mathrm{e}^{-7}$ & 12.2 & 34.6 & 0.55 \\
\hline 3 & Alb. Sea & 36.28 & -4.976 & 0.436 & 29.7 & 35.78 & 0.93 & $8.2 \mathrm{e}^{-7}$ & 29 & 49.4 & 0.68 \\
\hline 4 & Alb. Sea & 36.28 & -4.975 & 0.43 & 30.23 & 37.15 & 0.92 & $9.4 \mathrm{e}^{-7}$ & 40.2 & 32.9 & 0.65 \\
\hline 5 & Alb. Sea & 36.29 & -4.97 & 0.415 & 29.50 & 40.67 & 0.92 & $7.0 \mathrm{e}^{-7}$ & 34.6 & 43.7 & 0.69 \\
\hline 6 & Alb. Sea & 36.29 & -4.964 & 0.42 & 32.45 & 51.01 & 0.92 & $9.3 \mathrm{e}^{-7}$ & 26.4 & 18.9 & 0.64 \\
\hline 7 & Alb. Sea & 36.3 & -4.957 & 0.434 & 41.29 & 63.83 & 0.88 & $6.6 \mathrm{e}^{-7}$ & 39.3 & 86.6 & 0.65 \\
\hline 8 & Alb. Sea & 36.3 & -4.954 & 0.426 & 22.25 & 41.92 & 0.93 & $4.7 \mathrm{e}^{-7}$ & 27.1 & 49.2 & 0.54 \\
\hline 9 & Gibraltar & 35.92 & -5.68 & 0.175 & 25.95 & 27.35 & 0.92 & $7.8 \mathrm{e}^{-6}$ & 24.5 & 24.1 & 0.8 \\
\hline 10 & Gibraltar & 36.0 & -5.67 & 0.14 & 12.67 & 27.67 & 0.87 & $5.6 \mathrm{e}^{-7}$ & 10.31 & 26 & 0.56 \\
\hline 11 & Gibraltar & 35.9 & -5.69 & 0.16 & 12.27 & 37.26 & 0.87 & $7.9 \mathrm{e}^{-6}$ & 9.87 & 32.4 & 0.63 \\
\hline 12 & Gibraltar & 35.92 & -5.76 & 0.162 & 18.89 & 54.3 & 0.84 & $2.1 \mathrm{e}^{-6}$ & 12.7 & 22.1 & 0.8 \\
\hline 13 & Gibraltar & 35.92 & -5.77 & 0.173 & 20.26 & 60.65 & 0.91 & $9.1 \mathrm{e}^{-7}$ & 6.67 & 34.3 & 0.66 \\
\hline 14 & Gibraltar & 35.92 & -5.79 & 0.411 & 32.45 & 51.06 & 0.91 & $9.3 \mathrm{e}^{-7}$ & 12.6 & 18.9 & 0.65 \\
\hline 15 & Gibraltar & 35.91 & -5.78 & 0.216 & 19.70 & 54.58 & 0.87 & $9.7 \mathrm{e}^{-7}$ & 19 & 30.7 & 0.64 \\
\hline 16 & Gibraltar & 35.93 & -5.79 & 0.21 & 35.98 & 55.57 & 0.9 & $4.1 \mathrm{e}^{-6}$ & 12.6 & 14.2 & 0.58 \\
\hline 17 & Gibraltar & 35.94 & -5.69 & 0.187 & 31.83 & 57.72 & 0.90 & $1.8 \mathrm{e}^{-6}$ & 4.81 & 16.8 & 0.59 \\
\hline 18 & Gibraltar & 35.92 & -5.7 & 0.116 & 11.03 & 41.91 & 0.68 & $7.7 \mathrm{e}^{-6}$ & 12.6 & 14.5 & 0.9 \\
\hline 19 & Gibraltar & 35.92 & -5.79 & 0.224 & 30.54 & 51.13 & 0.89 & $3.6 \mathrm{e}^{-6}$ & 23.1 & 15.5 & 0.65 \\
\hline 20 & Gibraltar & 35.93 & -5.68 & 2.90 & 11.65 & 31.06 & 0.92 & $1.6 \mathrm{e}^{-5}$ & 4.49 & 11.9 & 0.57 \\
\hline 21 & Gibraltar & 35.92 & -5.63 & 0.42 & 14.36 & 33.42 & 0.95 & $1.9 \mathrm{e}^{-6}$ & 31.2 & 10 & 0.85 \\
\hline 22 & Gibraltar & 35.92 & -5.8 & 0.26 & 24.48 & 42.42 & 0.91 & $4.2 \mathrm{e}^{-6}$ & 6.7 & 12 & 0.53 \\
\hline 23 & Antarctic & -63.47 & -56.64 & 0.95 & 20.63 & 34.85 & 0.94 & $6.8 \mathrm{e}^{-8}$ & 17.5 & 13 & 0.77 \\
\hline 24 & Antarctic & -61.47 & -56.64 & 0.883 & 17.39 & 36.01 & 0.98 & $2.3 \mathrm{e}^{-8}$ & 8.8 & 10.2 & 0.59 \\
\hline 25 & Antarctic & -61.28 & -57.58 & 0.39 & 24.09 & 83.45 & 0.97 & $9 \mathrm{e}^{-7}$ & 13.7 & 81.4 & 0.95 \\
\hline 26 & Antarctic & -62.77 & -58.72 & 0.37 & 23.38 & 81.56 & 0.96 & $3.1 \mathrm{e}^{-7}$ & 9.94 & 72.7 & 0.88 \\
\hline 27 & Antarctic & -63.45 & -56.59 & 0.36 & 22.9 & 76.92 & 0.97 & $2.9 \mathrm{e}^{-7}$ & 8.4 & 72 & 0.83 \\
\hline 28 & Antarctic & -63.43 & -56.61 & 0.65 & 20.88 & 90.07 & 0.96 & $9.6 \mathrm{e}^{-8}$ & 14.4 & 70.8 & 0.81 \\
\hline 29 & Antarctic & -61.33 & -60.6 & 0.61 & 14.73 & 67.59 & 0.96 & $9.4 \mathrm{e}^{-8}$ & 15.7 & 54.3 & 0.84 \\
\hline 30 & North. Atl. & 34.66 & -8.78 & 0.392 & 14.76 & 98.97 & 0.90 & $1.1 \mathrm{e}^{-6}$ & 12.8 & 77.3 & 0.79 \\
\hline 31 & North. Atl. & 34.83 & -8.23 & 0.24 & 27.98 & 98.96 & 0.96 & $1.6 \mathrm{e}^{-6}$ & 17.7 & 43.1 & 0.76 \\
\hline
\end{tabular}

